\title{
Human 8-oxoguanine DNA glycosylase gene polymorphism (Ser326Cys) and cancer risk: updated meta-analysis
}

\author{
Sang Wook Kang ${ }^{2, *}$, Su Kang Kim ${ }^{1, *}$, Hae Jeong Park ${ }^{1}$, Joo-Ho Chung ${ }^{1}$ and Ju Yeon \\ Ban $^{2}$ \\ ${ }^{1}$ Kohwang Medical Institute, School of Medicine, Kyung Hee University, Seoul, Republic of Korea \\ 2 Department of Dental Pharmacology, School of Dentistry, Dankook University, Cheonan, Republic of Korea \\ ${ }^{*}$ First two authors equally contributed
}

Correspondence to: Ju Yeon Ban, email: jyban@dankook.ac.kr

Keywords: hOGG1, polymorphism, Ser326Cys, cancer, meta-analysis

Received: September 27, $2016 \quad$ Accepted: March 03, $2017 \quad$ Published: March 15, 2017

Copyright: Kang et al. This is an open-access article distributed under the terms of the Creative Commons Attribution License 3.0 (CC BY 3.0), which permits unrestricted use, distribution, and reproduction in any medium, provided the original author and source are credited.

\section{ABSTRACT}

Genetic polymorphism of human 8-oxoguanine glycosylase 1 (hOGG1) has been reported to have a relationship with the risk of the development of various cancers. Many studies have described the influence of Ser326Cys polymorphism of the hOGG1 gene on cancer susceptibility. However, the results have remained inconclusive and controversial. Therefore, we performed a meta-analysis to more precisely determine the relationship between the hOGG1 polymorphism and the development of cancer.

Electronic databases including PubMed, Embase, Google Scholar, and the Korean Studies Information Service System (KISS) were searched. The odds ratio (OR), 95\% confidence interval ( $\mathrm{CI}$ ), and $\mathrm{p}$ value were calculated to assess the strength of the association with the risk of cancer using Comprehensive Meta-analysis software (Corporation, NJ, USA). The 127 studies including 38,757 cancer patients and 50,177 control subjects were analyzed for the meta-analysis.

Our meta-analysis revealed that G allele of Ser326Cys polymorphism of the hOGG1 gene statistically increased the susceptibility of cancer (all population, OR = $1.092,95 \%$ CI $=1.051-1.134, p<0.001$; in Asian, OR $=1.095,95 \%$ CI $=1.048-1.145$, $p<0.001$; in Caucasian, OR $=1.097,95 \% \mathrm{CI}=1.033-1.179, p=0.002)$. Also, other genotype models showed significant association with cancer $(p<0.05$, respectively).

The present meta-analysis concluded that the $\mathbf{G}$ allele was associated with an increased risk of cancer. It suggested that the hOGG1 polymorphism may be a candidate marker of cancer.

\section{INTRODUCTION}

Cancers are serious problem around the world and complex, multistep, multifactorial, and highly fatal diseases. The environment and genetic inheritance have been known as risk factor in development of cancer [1]. Several recent studies focused on the genetic background and how the single nucleotide polymorphism (SNP) of specific genes, including DNA damage, can enhance cancer susceptibility [2].

DNA damage plays an important role in tumor development. Reactive oxygen species (ROS) increases damage to DNA and causes miscoding by
DNA polymerase [3]. The level of ROS in tissue DNA reflects a balance between the rate of damage and repair. Abnormal balance results in DNA mutations that can activate oncogenes or inactivate tumor suppressor genes, which leads to cancer [4]. The base excision repair (BER) pathway is one of the DNA repair process. An important role of BER is to remove DNA damage caused by various carcinogens, such as ionizing radiation or reactive oxidative species [5]. BER has also evolved to cope with mutagenic and cytotoxic hydrolytic, oxidative, and alkylation damages. A relationship of BER to cancer progression has been drawn from the observation that mutations or altered expression in BER genes [6]. 
The hOGG1 is a DNA repair enzyme that excises 7,8-dihydro-8-oxoguanine (8oxoG) from DNA. The $h O G G 1$ is located on chromosome $3 \mathrm{p} 26$, a vital member of the BER pathway, and encodes 8-oxoguanine glycosylase that is a key enzyme in the repair of 8-oxoguanine [7]. ROS can lead to mutagenic base $80 x 0$ G formation in DNA and carcinogenesis [8]. Since 8oxoG is a highly mispairing lesion, it was suggested that decreased hOGG1expression level could lead to a higher background mutation frequency and could possibly increase the cancer risk of an individual under oxidative stress [7].

Many previous studies showed the relationship between the Ser326Cys polymorphism of $h O G G 1$ gene and cancer susceptibility. Meta-analysis on the $h O G G 1$ polymorphism and the risk of bladder cancer shows no statistically significant association [9]. The meta-analysis on breast cancer suggested that the allele of $h O G G 1$ 326 Cys plays a protective effect in European women but not in different menopausal status (premenopausal and postmenopausal) or the other ethnicities (Asians and Americans) [10]. The hOGG1 polymorphism may be also contributed to the susceptibility of digestive cancers [11], colorectal cancer [12], esophageal squamous cell carcinoma [13] but shows a lack of association in gastric cancer [14]. In addition, the $h O G G 1$ polymorphism is associated with hepatocellular carcinoma [15], head and neck cancer [16], and prostate cancer [17], not with lung cancer [18].

Meta-analysis study in 2011 year reported that the evidence of the association between the hOGG1 polymorphism and cancer risk [19]. Since 2011, many studies reported the relation between the hOGG1 polymorphism and various cancer risks. However, the results have not been updated yet. Therefore, the purpose of this meta-analysis is to update previous meta-analysis with the aim of elucidating the association of the $h O G G 1$ polymorphism and risk of cancer.

\section{RESULTS}

In present study, we performed the meta-analysis to assess relationship between the hOGG1 polymorphism and risk of cancer. We collected the genetic data from electronic databases. The search strategy used for this meta-analysis is shown in Figure 1. We examined the 577 articles and 442 articles were excluded as they were unrelated articles or duplicated studies. Among them, 19 studies were excluded because they were not consistent with Hardy-Weinberg equilibrium (HWE). After 116 articles were selected, 11 studies about the $h O G G 1$ polymorphism since 2012 were added. Finally, a total of 127 genetic studies about the $h O G G 1$ polymorphism and cancer were analyzed for meta-analysis (Supplementary Table 1) [5, 10-143]. Supplementary Table 1 shows basic characteristics of the analyzed studies. The total 88,934 individuals comprised of 38,757 cancer patients and 50,177 control subjects. The types of cancers were including colorectal (18 articles), lung (28 articles), breast (16 articles), bladder (4 articles), gallbladder (2 articles), prostate ( 7 articles), gastric (13 articles), esophageal (10 articles), head and neck (8 articles), hepatocellular cancers (7 articles), and etc.

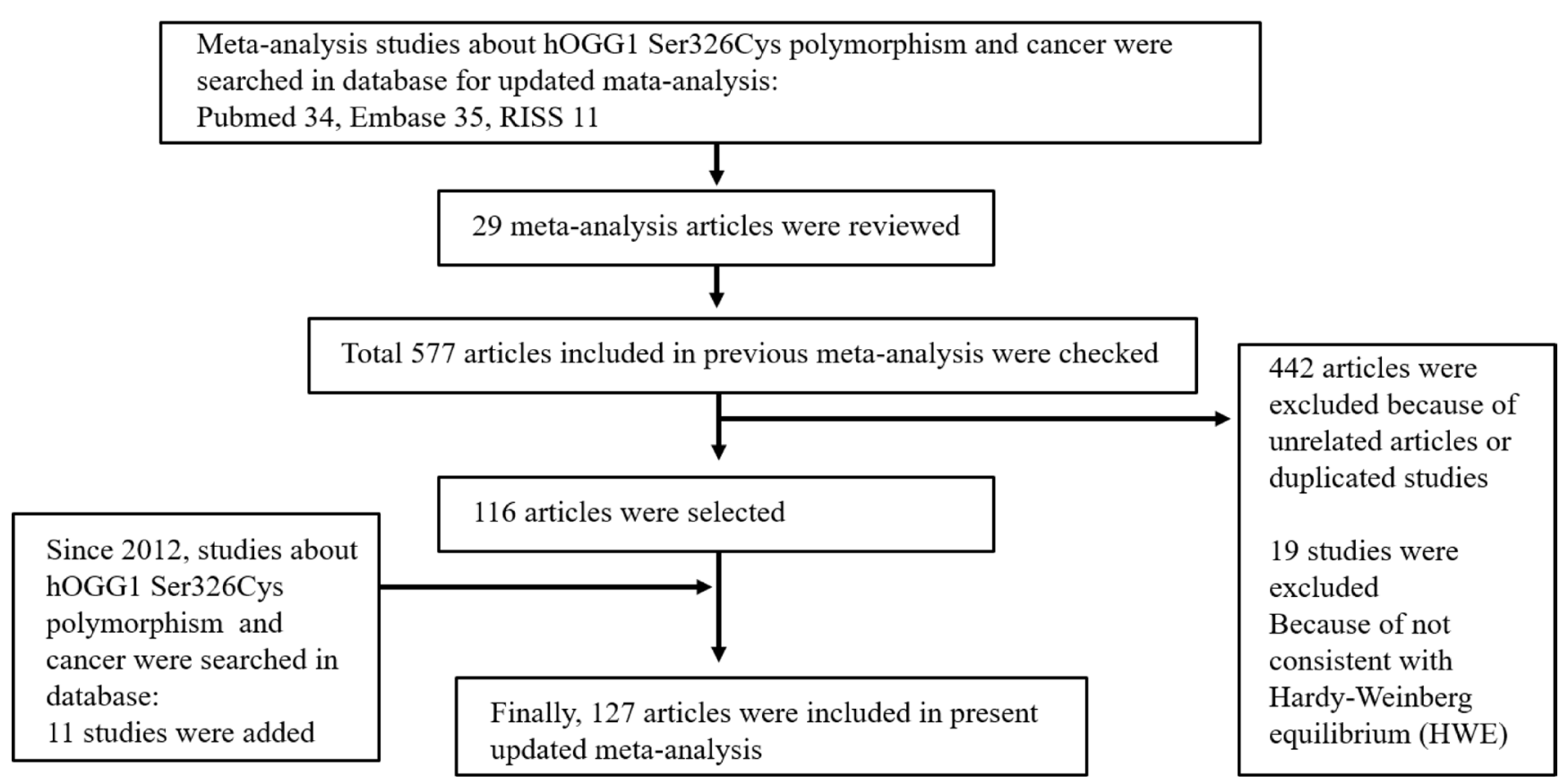

Figure 1: Flow chart illustrating the search strategy used for this meta-analysis to identify studies that examined the association between $h O G G 1$ Ser326Cys polymorphism and risk of cancer. 
Table 1: Overall analysis between $h O G G 1$ Ser326Cys polymorphism and risk of cancer

\begin{tabular}{|c|c|c|c|c|c|c|}
\hline \multirow{2}{*}{ Cancers } & \multirow{2}{*}{ No. of studies } & \multicolumn{2}{|c|}{ Heterogeneity } & \multirow{2}{*}{ Model } & \multirow{2}{*}{ OR $(95 \%$ CI $)$} & \multirow{2}{*}{$p$} \\
\hline & & $p$ & I-squared & & & \\
\hline \multicolumn{7}{|l|}{ Cvs. G } \\
\hline All cancers & 125 & $<0.001$ & 61.138 & Random & $1.092(1.051-1.134)$ & $<0.001$ \\
\hline Colorectal cancer & 17 & $<0.001$ & 65.928 & Random & $1.121(1.005-1.251)$ & 0.040 \\
\hline Lung cancer & 28 & $<0.001$ & 51.835 & Random & $1.094(1.020-1.172)$ & 0.012 \\
\hline Breast cancer & 16 & 0.077 & 35.7 & Fixed & $1.031(0.985-1.079)$ & 0.185 \\
\hline Bladder cancer & 4 & 0.004 & 77.187 & Random & $1.058(0.812-1.379)$ & 0.676 \\
\hline Gallbladder cancer & 2 & 0.015 & 83.061 & Random & $1.044(0.877-1.242)$ & 0.627 \\
\hline Prostate cancer & 6 & $<0.001$ & 79.676 & Random & $1.459(1.068-1.992)$ & 0.018 \\
\hline Gastric cancer & 13 & 0.034 & 46.33 & Random & $1.011(0.883-1.157)$ & 0.874 \\
\hline Esophageal cancer & 10 & 0.112 & 37.044 & Fixed & $1.050(0.957-1.152)$ & 0.299 \\
\hline Head and neck cancer & 8 & $<0.001$ & 77.552 & Random & $1.335(1.079-1.651)$ & 0.008 \\
\hline Hepatocellular cancer & 7 & $<0.001$ & 74.985 & Random & $1.089(0.883-1.344)$ & 0.424 \\
\hline Acute lymphoblastic leukemia & 2 & 0.002 & 89.539 & Random & $1.579(0.775-3.217)$ & 0.208 \\
\hline Pancreatic adenocarcinoma & 2 & 0.467 & $<0.001$ & Fixed & $1.007(0.885-1.146)$ & 0.917 \\
\hline \multicolumn{7}{|l|}{$\mathrm{C} / \mathrm{C}$ vs. $\mathrm{C} / \mathrm{G}+\mathrm{G} / \mathrm{G}$} \\
\hline All cancers & 127 & $<0.001$ & 56.428 & Random & $1.079(1.027-1.134)$ & 0.002 \\
\hline Colorectal cancer & 18 & $<0.001$ & 60.869 & Random & $1.140(0.993-1.308)$ & 0.063 \\
\hline Lung cancer & 28 & 0.004 & 47.036 & Random & $1.080(0.984-1.187)$ & 0.106 \\
\hline Breast cancer & 16 & 0.202 & 22.109 & Fixed & $1.011(0.948-1.078)$ & 0.742 \\
\hline Bladder cancer & 4 & 0.39 & 0.312 & Fixed & $1.000(0.847-1.181)$ & 0.996 \\
\hline Gallbladder cancer & 2 & 0.029 & 78.918 & Random & $1.080(0.644-1.812)$ & 0.771 \\
\hline Prostate cancer & 7 & $<0.001$ & 75.606 & Random & $1.401(0.976-2.011)$ & 0.067 \\
\hline Gastric cancer & 13 & 0.346 & 9.913 & Fixed & $0.928(0.821-1.048)$ & 0.229 \\
\hline Esophageal cancer & 10 & 0.199 & 26.588 & Fixed & $0.971(0.854-1.104)$ & 0.652 \\
\hline Head and neck cancer & 8 & $<0.001$ & 74.243 & Random & $1.424(1.099-1.845)$ & 0.007 \\
\hline Hepatocellular cancer & 7 & $<0.001$ & 88.181 & Random & $1.113(0.673-1.841)$ & 0.677 \\
\hline Acute lymphoblastic leukemia & 2 & 0.006 & 86.606 & Random & $1.401(0.583-3.364)$ & 0.451 \\
\hline Pancreatic adenocarcinoma & 2 & 0.451 & $<0.001$ & Fixed & $1.051(0.898-1.230)$ & 0.539 \\
\hline \multicolumn{7}{|l|}{$\mathrm{C} / \mathrm{C}+\mathrm{C} / \mathrm{G}$ vs. $\mathrm{G} / \mathrm{G}$} \\
\hline All cancers & 125 & $<0.001$ & 54.586 & Random & $1.178(1.098-1.263)$ & $<0.001$ \\
\hline Colorectal cancer & 17 & 0.04 & 41.096 & Random & $1.154(0.959-1.388)$ & 0.129 \\
\hline Lung cancer & 28 & 0.03 & 36.264 & Random & $1.188(1.055-1.337)$ & 0.004 \\
\hline Breast cancer & 16 & 0.378 & 6.626 & Fixed & $1.092(1.004-1.189)$ & 0.041 \\
\hline Bladder cancer & 4 & $<0.001$ & 86.372 & Random & $1.118(0.557-2.246)$ & 0.753 \\
\hline Gallbladder cancer & 2 & 0.074 & 68.567 & Fixed & $1.099(0.761-1.585)$ & 0.615 \\
\hline Prostate cancer & 6 & 0.003 & 72.07 & Random & $1.691(0.965-2.965)$ & 0.066 \\
\hline Gastric cancer & 13 & 0.037 & 46.74 & Random & $1.088(0.823-1.438)$ & 0.553 \\
\hline Esophageal cancer & 10 & 0.02 & 54.195 & Random & $1.252(0.929-1.686)$ & 0.139 \\
\hline Head and neck cancer & 8 & 0.009 & 62.394 & Random & $1.551(1.045-2.301)$ & 0.029 \\
\hline Hepatocellular cancer & 7 & $<0.001$ & 85.472 & Random & $1.126(0.723-1.754)$ & 0.600 \\
\hline Acute lymphoblastic leukemia & 2 & 0.011 & 84.554 & Random & $2.435(0.632-9.376)$ & 0.196 \\
\hline Pancreatic adenocarcinoma & 2 & 0.809 & $<0.001$ & Fixed & $0.823(0.578-1.172)$ & 0.280 \\
\hline
\end{tabular}

OR odds ratio, vs versus. Bold numbers indicate significant association with risk of cancer.

Table 1 presents the results of meta-analysis of association between the $h O G G 1$ polymorphism and risk of cancer in allele $(\mathrm{C} v s . \mathrm{G})$, dominant $(\mathrm{C} / \mathrm{C}$ genotype vs. $\mathrm{C} / \mathrm{G}+\mathrm{G} / \mathrm{G}$ genotypes $)$, and recessive $(\mathrm{C} / \mathrm{C}+\mathrm{C} / \mathrm{G}$ genotypes vs. G/G genotype) models. The frequencies of major allele $\mathrm{C} /$ minor allele $\mathrm{G}$ in the total cancer and control were $63.33 \% / 36.67 \%$ and $65.34 \% / 34.66 \%$. The minor $\mathrm{G}$ allele frequency in the total cancer was higher more than that of control (36.67\% vs. 34.66\%). The difference showed the significantly strong association with risk of cancer $(\mathrm{OR}=1.088,95 \% \mathrm{CI}=1.048-1.130, p<0.001$ in Table 1$)$. In the subgroup according to type cancer, as shown in Table 1, colorectal cancer, lung cancer, prostate cancer and head and neck cancer presented the association with risk of cancer (colorectal cancer, $\mathrm{OR}=1.121,95 \% \mathrm{CI}=1.005$ $1.251, p=0.040$; lung cancer, $\mathrm{OR}=1.094,95 \% \mathrm{CI}=1.020$ - 
Table 2: Overall analysis between $h O G G 1 \mathrm{Ser326Cys}$ polymorphism and risk of cancer in Asian

\begin{tabular}{|c|c|c|c|c|c|c|}
\hline \multirow{2}{*}{ Cancers } & \multirow{2}{*}{ Comparison } & \multicolumn{2}{|c|}{ Heterogeneity } & \multirow{2}{*}{ Model } & \multirow{2}{*}{ OR (95\% CI) } & \multirow{2}{*}{$p$} \\
\hline & & $p$ & I-squared & & & \\
\hline \multirow{3}{*}{ All cancers } & C vs. G & $<0.001$ & 44.278 & Random & $1.095(1.048-1.145)$ & $<0.001$ \\
\hline & CC vs. CG+GG & $<0.001$ & 48.900 & Random & $1.096(1.015-1.183)$ & 0.019 \\
\hline & $\mathrm{CC}+\mathrm{CG} v s . \mathrm{GG}$ & $<0.001$ & 63.487 & Random & $1.171(1.070-1.282)$ & 0.001 \\
\hline \multirow{3}{*}{ Colorectal cancer } & C vs. G & 0.149 & 47.481 & Fixed & $0.987(0.879-1.108)$ & 0.822 \\
\hline & CC vs. CG+GG & 0.123 & $<0.001$ & Fixed & $1.068(0.868-1.315)$ & 0.532 \\
\hline & $\mathrm{CC}+\mathrm{CG} v s . \mathrm{GG}$ & 0.451 & $<0.001$ & Fixed & $0.945(0.795-1.122)$ & 0.517 \\
\hline \multirow{3}{*}{ Lung cancer } & Cvs. G & 0.487 & $<0.001$ & Fixed & $1.110(1.048-1.176)$ & $<0.001$ \\
\hline & CC vs. CG+GG & 0.163 & 27.193 & Fixed & $1.116(1.013-1.229)$ & 0.027 \\
\hline & $\mathrm{CC}+\mathrm{CG} v s . \mathrm{GG}$ & 0.220 & 21.505 & Fixed & $1.176(1.074-1.289)$ & 0.000 \\
\hline \multirow{3}{*}{ Breast cancer } & C vs. G & 0.376 & 6.340 & Fixed & $1.085(1.013-1.162)$ & 0.019 \\
\hline & CC vs. $\mathrm{CG}+\mathrm{GG}$ & 0.942 & $<0.001$ & Fixed & $1.098(0.971-1.241)$ & 0.135 \\
\hline & $\mathrm{CC}+\mathrm{CG} v s . \mathrm{GG}$ & 0.108 & 44.685 & Fixed & $1.122(1.014-1.242)$ & 0.026 \\
\hline \multirow{3}{*}{ Bladder cancer } & C vs. G & 0.018 & 75.198 & Random & $1.135(0.821-1.571)$ & 0.444 \\
\hline & CC vs. CG+GG & 0.848 & $<0.001$ & Fixed & $1.157(0.910-1.472)$ & 0.235 \\
\hline & $\mathrm{CC}+\mathrm{CG} v s . \mathrm{GG}$ & $<0.001$ & 89.184 & Random & $1.264(0.503-3.174)$ & 0.619 \\
\hline \multirow{3}{*}{ Gallbladder cancer } & C vs. G & 0.015 & 83.061 & Random & $1.108(0.710-1.728)$ & 0.652 \\
\hline & $\mathrm{CC} v s . \mathrm{CG}+\mathrm{GG}$ & 0.029 & 78.918 & Random & $1.080(0.644-1.812)$ & 0.771 \\
\hline & $\mathrm{CC}+\mathrm{CG} v s . \mathrm{GG}$ & 0.074 & 68.567 & Fixed & $1.099(0.761-1.585)$ & 0.615 \\
\hline \multirow{3}{*}{ Gastric cancer } & Cvs. G & 0.075 & 49.976 & Fixed & $1.010(0.904-1.129)$ & 0.855 \\
\hline & CC vs. CG+GG & 0.561 & $<0.001$ & Fixed & $0.977(0.811-1.176)$ & 0.802 \\
\hline & $\mathrm{CC}+\mathrm{CG} v s . \mathrm{GG}$ & 0.012 & 65.907 & Random & $1.232(0.823-1.843)$ & 0.311 \\
\hline \multirow{3}{*}{ Esophageal cancer } & C vs. G & 0.837 & $<0.001$ & Fixed & $1.087(0.980-1.205)$ & 0.113 \\
\hline & CC vs. CG+GG & 0.733 & $<0.001$ & Fixed & $1.017(0.875-1.182)$ & 0.821 \\
\hline & $\mathrm{CC}+\mathrm{CG} v s . \mathrm{GG}$ & 0.031 & 56.757 & Random & $1.277(0.939-1.735)$ & 0.119 \\
\hline \multirow{3}{*}{ Head and neck cancer } & C vs. G & 0.020 & 81.661 & Random & $1.499(0.729-3.084)$ & 0.271 \\
\hline & CC vs. $\mathrm{CG}+\mathrm{GG}$ & 0.274 & 16.259 & Fixed & $1.856(1.262-2.731)$ & 0.002 \\
\hline & $\mathrm{CC}+\mathrm{CG} v s . \mathrm{GG}$ & 0.124 & 57.636 & Fixed & $0.964(0.696-1.335)$ & 0.825 \\
\hline \multirow{3}{*}{ Hepatocellular cancer } & C vs. G & 0.001 & 74.985 & Random & $1.089(0.883-1.344)$ & 0.424 \\
\hline & $\mathrm{CC} v s . \mathrm{CG}+\mathrm{GG}$ & $<0.001$ & 89.658 & Random & $1.113(0.673-1.841)$ & 0.677 \\
\hline & $\mathrm{CC}+\mathrm{CG} v s . \mathrm{GG}$ & $<0.001$ & 85.472 & Random & $1.126(0.723-1.754)$ & 0.600 \\
\hline
\end{tabular}

OR odds ratio, vs versus. Bold numbers indicate significant association with risk of cancer.

$1.172, p=0.012$; prostate cancer $\mathrm{OR}=1.459,95 \% \mathrm{CI}=1.068$ 1.992, $p=0.018$; head and neck cancer, $\mathrm{OR}=1.335,95 \%$ $\mathrm{CI}=1.079-1.651, p=0.008)$. The frequencies of $\mathrm{CC}$ genotype/CG+GG genotypes in the total cancer and control were $43.17 \% / 56.83 \%$ and $45.02 \% / 54.98 \%$. The $\mathrm{CG}+\mathrm{GG}$ genotypes frequency in the total cancer was higher more than that of control (56.83\% vs. 54.98\%). The difference showed the significant association with risk of cancer $(\mathrm{OR}=1.075,95 \% \mathrm{CI}=1.023-1.130, p=0.004$ in Table 1). In the subgroup according to type cancer, head and neck cancer only showed the association with risk of cancer (head and neck cancer, OR=1.424, 95\% $\mathrm{CI}=1.099-1.845, p=0.007)$. The frequencies of $\mathrm{CC}+\mathrm{CG}$ genotypes/GG genotype in the total cancer and control were $83.56 \% / 16.44 \%$ and $85.69 \% / 14.31 \%$. The $\mathrm{CG}+\mathrm{GG}$ genotypes frequency in the total cancer was higher more than that of control (16.44\% vs. 14.31\%). The difference showed the significant association with risk of cancer
$(\mathrm{OR}=1.174,95 \% \mathrm{CI}=1.094-1.259, p<0.001$ in Table 1$)$. In the subgroup according to type cancer, lung cancer and head and neck cancer presented the association with risk of cancer (lung cancer, $\mathrm{OR}=1.188,95 \% \mathrm{CI}=1.055$ $1.337, p=0.004$; head and neck cancer, $\mathrm{OR}=1.551,95 \%$ $\mathrm{CI}=1.045-2.301, p=0.029$ ).

Table 2 and Table 3 present the results of metaanalysis of association between the $h O G G 1$ polymorphism and risk of cancer according to ethnic difference. In Asian population, analysis of allele, dominant, and recessive models showed the association with risk of cancer (C vs. $\mathrm{G}, \mathrm{OR}=1.095,95 \% \mathrm{CI}=1.048-1.145, p<0.001$ : $\mathrm{CC}$ vs. $\mathrm{CG}+\mathrm{GG}, \mathrm{OR}=1.096,95 \% \quad \mathrm{CI}=1.015-1.183$, $\mathrm{p}=0.019 ; \mathrm{CC}+\mathrm{CG}$ vs. $\mathrm{GG}, \mathrm{OR}=1.171,95 \% \mathrm{CI}=1.070$ 1.282, $p=0.001$ in Table 2). According to the type of cancer, risk of lung, breast, and head and neck cancers was associated with the $h O G G 1$ polymorphism $(p<0.05$, Table 2). In Caucasian population, analysis of allele 
Table 3: Overall analysis between $h O G G 1 \mathrm{Ser} 326 \mathrm{Cys}$ polymorphism and risk of cancer in Caucasian

\begin{tabular}{|c|c|c|c|c|c|c|}
\hline \multirow{2}{*}{ Cancers } & \multirow{2}{*}{ Comparison } & \multicolumn{2}{|c|}{ Heterogeneity } & \multirow{2}{*}{ Model } & \multirow{2}{*}{ OR $(95 \%$ CI $)$} & \multirow{2}{*}{$p$} \\
\hline & & $p$ & I-squared & & & \\
\hline \multirow{3}{*}{ All cancers } & C vs. G & $<0.001$ & 68.987 & Random & $1.097(1.033-1.166)$ & 0.002 \\
\hline & $\mathrm{CC} v s . \mathrm{CG}+\mathrm{GG}$ & $<0.001$ & 62.672 & Random & $1.078(1.007-1.154$ & 0.031 \\
\hline & $\mathrm{CC}+\mathrm{CG} v s . \mathrm{GG}$ & $<0.001$ & 45.629 & Random & $1.183(1.053-1.331)$ & 0.004 \\
\hline \multirow{3}{*}{ Colorectal cancer } & C vs. G & $<0.001$ & 74.844 & Random & $1.255(1.053-1.497)$ & 0.011 \\
\hline & CC vs. CG+GG & $<0.001$ & 73.239 & Random & $1.234(1.004-1.516)$ & 0.045 \\
\hline & $\mathrm{CC}+\mathrm{CG} v s . \mathrm{GG}$ & 0.036 & 49.696 & Random & $1.509(1.031-2.211)$ & 0.034 \\
\hline \multirow{3}{*}{ Lung cancer } & C vs. G & $<0.001$ & 74.319 & Random & $1.097(0.920-1.309)$ & 0.303 \\
\hline & CC vs. CG+GG & 0.001 & 67.238 & Random & $1.081(0.895-1.306)$ & 0.420 \\
\hline & $\mathrm{CC}+\mathrm{CG} v s . \mathrm{GG}$ & 0.034 & 50.306 & Random & $1.175(0.814-1.696)$ & 0.389 \\
\hline \multirow{3}{*}{ Breast cancer } & C vs. G & 0.117 & 36.459 & Fixed & $0.990(0.932-1.053)$ & 0.756 \\
\hline & CC vs. CG+GG & 0.075 & 42.399 & Fixed & $0.980(0.909-1.056)$ & 0.596 \\
\hline & $\mathrm{CC}+\mathrm{CG} v s . \mathrm{GG}$ & 0.728 & $<0.001$ & Fixed & $1.026(0.880-1.197)$ & 0.739 \\
\hline \multirow[t]{3}{*}{ Prostate cancer } & C vs. G & $<0.001$ & 90.407 & Random & $1.397(0.702-2.780)$ & 0.342 \\
\hline & CC vs. CG+GG & 0.001 & 85.774 & Random & $1.503(0.734-3.078)$ & 0.265 \\
\hline & $\mathrm{CC}+\mathrm{CG} v s . \mathrm{GG}$ & $<0.001$ & 87.260 & Random & $1.604(0.344-7.479)$ & 0.548 \\
\hline \multirow[t]{3}{*}{ Gastric cancer } & C vs. G & 0.081 & 55.491 & Fixed & $0.889(0.752-1.050)$ & 0.166 \\
\hline & $\mathrm{CC} v s . \mathrm{CG}+\mathrm{GG}$ & 0.131 & 56.157 & Fixed & $0.880(0.722-1.073)$ & 0.207 \\
\hline & $\mathrm{CC}+\mathrm{CG} v s . \mathrm{GG}$ & 0.467 & $<0.001$ & Fixed & $0.802(0.498-1.292)$ & 0.364 \\
\hline \multirow[t]{3}{*}{ Esophageal cancer } & C vs. G & 0.149 & 52.096 & Fixed & $0.660(0.482-0.904)$ & 0.148 \\
\hline & $\mathrm{CC} v s . \mathrm{CG}+\mathrm{GG}$ & 0.102 & 51.614 & Fixed & $0.627(0.434-0.905)$ & 0.013 \\
\hline & $\mathrm{CC}+\mathrm{CG} v s . \mathrm{GG}$ & 0.943 & $<0.001$ & Fixed & $0.427(0.144-1.263)$ & 0.124 \\
\hline \multirow[t]{3}{*}{ Head and neck cancer } & C vs. G & $<0.001$ & 83.256 & Random & $1.396(1.001-1.946)$ & 0.049 \\
\hline & $\mathrm{CC} v s . \mathrm{CG}+\mathrm{GG}$ & 0.001 & 79.552 & Random & $1.406(0.975-2.027)$ & 0.068 \\
\hline & $\mathrm{CC}+\mathrm{CG} v s . \mathrm{GG}$ & 0.014 & 67.859 & Random & $2.037(1.047-3.960)$ & 0.036 \\
\hline \multirow[t]{3}{*}{ Pancreatic adenocarcinoma } & C vs. G & 0.562 & $<0.001$ & Fixed & $1.007(0.885-1.146)$ & 0.917 \\
\hline & CC vs. $\mathrm{CG}+\mathrm{GG}$ & 0.451 & $<0.001$ & Fixed & $1.051(0.898-1.230)$ & 0.539 \\
\hline & $\mathrm{CC}+\mathrm{CG} v s . \mathrm{GG}$ & 0.809 & $<0.001$ & Fixed & $0.823(0.578-1.172)$ & 0.280 \\
\hline
\end{tabular}

OR odds ratio, vs versus. Bold numbers indicate significant association with risk of cancer.

and recessive models showed the association with risk of cancer $(\mathrm{C} v s . \mathrm{G}, \mathrm{OR}=1.097,95 \% \mathrm{CI}=1.021-1.179$, $p=0.012$ : $\mathrm{CC}+\mathrm{CG} v s . \mathrm{GG}, \mathrm{OR}=1.158,95 \% \mathrm{CI}=1.005$ 1.334, $p=0.043$ in Table 3). According to type of cancer, risk of colorectal, esophageal, and head and neck cancer was associated with the $h O G G 1$ polymorphism $(p<0.05$, Table 3). Begg's funnel plot and Egger's test were used to evaluate publication bias. The results of funnel plots and the Egger's test showed no publication bias in this meta-analysis except for allele model of all cancers (Figure 2). We found a weak publication bias in allele model of all cancers $(p=0.03425)$. In addition, 3 more subgroup analysis showed publication bias (recessive model of head and neck cancer and colorectal cancer in all population; recessive model of all cancer in Caucasian population, data not shown). In sensitivity analysis for our meta-analysis, some results were influenced by some studies. In all population analysis, allele model of lung, prostate, and head and neck cancer, dominant model of all cancers and head and neck cancer, and recessive model of all cancers, lung, and head and neck cancer were not influenced according to sensitivity analysis. In Asian population analysis, allele model of all cancers and lung cancer, dominant model of all cancers and head and neck cancer, and recessive model of all cancers, lung and breast cancer were not influenced. In Caucasian population analysis, allele model of all cancers and dominant model of esophageal cancer were not influenced by studies. These results indicate that individual with minor $\mathrm{G}$ allele of the $h O G G 1$ polymorphism may be increased risk of cancer.

\section{DISCUSSION}

It was suggested that cancer susceptibility could result from the interaction of genetic background. Exposure and reductions in DNA repair capacity by common genetic variation affect cancer predisposition [6]. The hOGG1 is generally involved in DNA repair, and has been studied extensively on its relationship with various types of cancer. Low OGG activity in peripheral blood mononuclear cells increases risk of lung cancer [144]. Also, lower expression of hOGG1 mRNA and hOGG1 protein decreases mitochondrial DNA repair to oxidative damage in lung cancer cells [145]. Immunohistochemical expressions in diffuse-type adenocarcinoma of gastric cardia showed lower expression of OGG1, which 
A. C vs. G

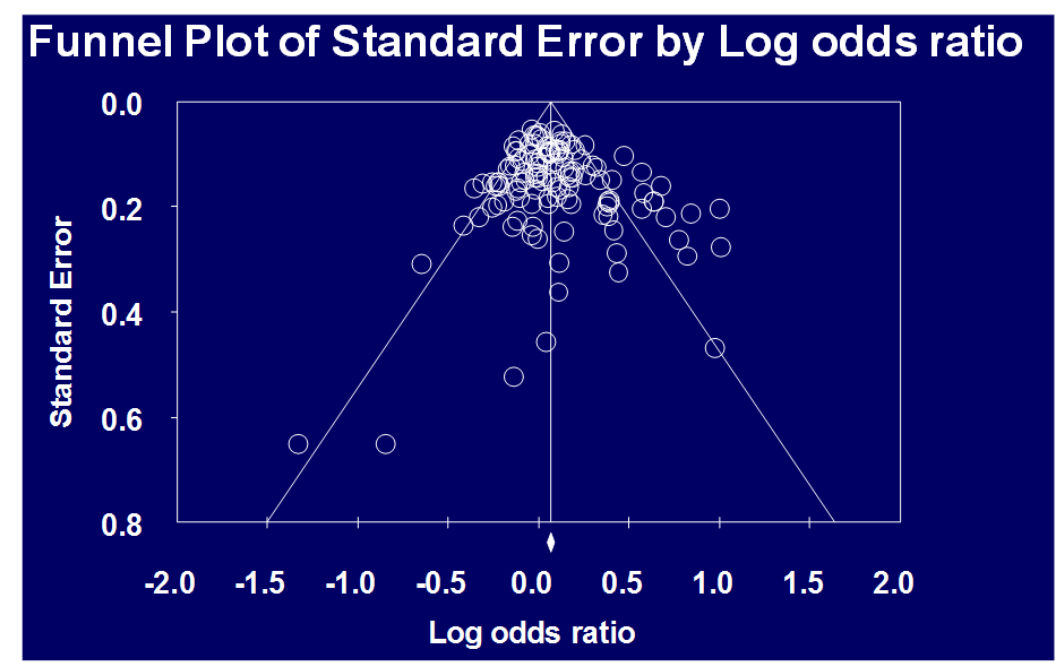

B. $\mathrm{CC} v s . \mathrm{CG}+\mathrm{GG}$
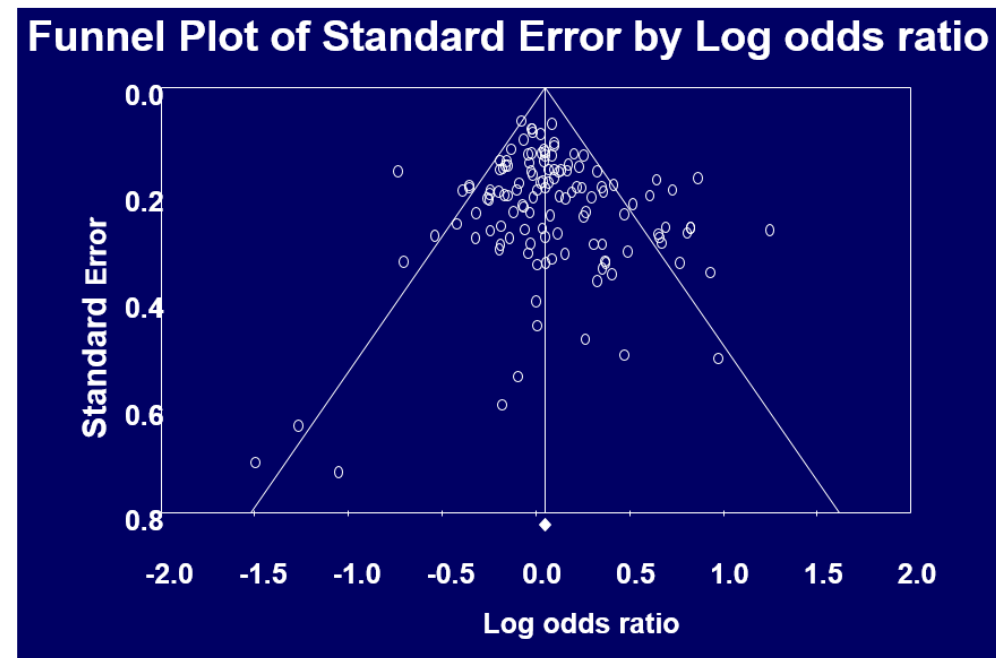

C. $\mathrm{CC}+\mathrm{CG} v s . \mathrm{GG}$

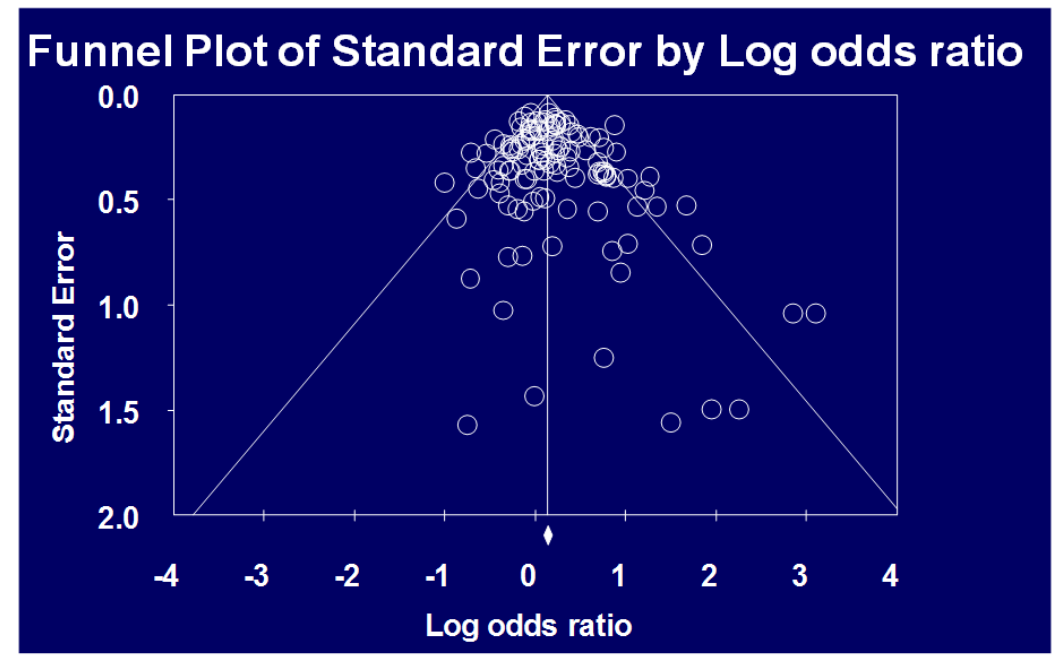

Figure 2: Begg's funnel plot for publication bias in selection of studies on the hOGG1 Ser326Cys polymorphism (C vs. $\mathrm{G}, \mathrm{C} / \mathrm{C}$ vs. $\mathrm{C} / \mathrm{G}+\mathrm{G} / \mathrm{G}$, and $\mathrm{C} / \mathrm{C}+\mathrm{C} / \mathrm{G}$ vs. $\mathrm{G} / \mathrm{G}$ in all population). 
related to higher T-stage, lymphatic invasion, and lymph node metastasis [146]. A previous study on lung cancer patients showed a close relationship between Ser326Cys polymorphism and OGG1 mRNA levels [57]. The Ser326Cys polymorphisms have been shown to be associated with delayed repair of oxidative DNA damage [147]. In a recent study, changes in the functional and structural characteristics of the hOGG1 protein by the Ser326Cys polymorphism using in silico computational biology tools have been reported. According to this study, hOGG1 326Cys variant is smaller and more hydrophobic than wild type, which can have deleterious effects on the function of the hOGG1 protein. And this variant has been found to be closely related to breast cancer [143]. Although the relationship between hOGG1 expression and cancer risk and the Ser326Cys $h O G G 1$ polymorphism and the expression of OGG1 has been reported, the results of previous genetic studies on the relationship between $h O G G 1$ polymorphism and various cancers risks were conflicting and contradictory. This meta-analysis was performed to provide a quantitative approach to for the different results.

Meta-analysis on the $h O G G 1$ polymorphism and the risk of bladder cancer, gastric cancer, and lung cancer shows no statistically significant association. But the other meta-analysis reported that the $h O G G 1$ polymorphism may contribute to the susceptibility of digestive cancers, breast cancer, colorectal cancer, esophageal squamous cell carcinoma, hepatocellular carcinoma, head and neck cancer, and prostate cancer. Among the previous metaanalysis studies, inappropriate data was included in the analysis. Therefore, there was error. For example, Zhu et al. 2012 investigated whether the $h O G G 1$ polymorphism was associated with prostate cancer using meta-analysis [17]. The meta-analysis included genotype data of rs3218997 SNP of $O G G 1$ that reported by Agalliu et al. 2010 [148]. Because rs3218997 SNP is different from Ser326Cys of $h O G G 1$, the genetic data had to be excluded for the exact meta-analysis. In addition, some previous studies included articles which were not consistent with HWE. We evaluated HWE in all the articles, some articles were excluded. So, we performed this meta-analysis to combine and update from the different results.

In present study, total of 126 genetic studies about the $h O G G 1$ polymorphism and cancer were analyzed for meta-analysis. Significant relationship between the $h O G G 1$ polymorphism and overall cancer risk was found. In subgroup analyses by cancer types, the significant association between the $h O G G 1$ polymorphism and colorectal, lung, prostate, and head and neck cancer risk was detected. In addition, in subgroup analyses by ethnicities, we found that the $h O G G 1$ polymorphism was significantly associated with overall cancer risk in both Caucasian and Asian population. But there was a little different result between Asian and Caucasian population. In Asian population, lung, breast, and head and neck cancer showed a relation with the hOGG1 polymorphism but in Caucasian population only head and neck cancer showed. On the other hands, an association with colorectal cancer and esophageal cancer was only shown in Caucasian population. Some our results were consistent with or contrary to previous meta-analysis. Overall cancer risk and the $h O G G 1$ polymorphism was significantly associated in our results (allele, $p<0.001$; dominant, $p=0.004$; recessive, $p<0.001$ ) and previous study showed similar result [19]. Results of previous meta-analysis on lung cancer were different from our present results [18]. Our results showed the statistically significance in lung cancer (allele and recessive model in overall analysis, allele, dominant, recessive model in Asian). It is seemed that it is because the previous study included some articles which were not in HWE in their meta-analysis. Meta-analysis on colorectal cancer was consistent with ours [12]. The hOGGl polymorphism had a connection with the colorectal cancer risk among the total population, and especially among Caucasians. One meta-analysis on breast cancer reported the association between the $h O G G 1$ polymorphism and breast cancer risk [10] but another study suggested a lack of association [149]. Our meta-analysis showed the different results. An association between the $h O G G 1$ polymorphism and breast cancer risk was found only in Asian population (allele, $p=0.019$; recessive model, $p=0.026$ ). Not only previous meta-analysis on bladder, gallbladder, and gastric cancer risk but also our present meta-analysis showed no statistically significance $[9,11,14]$. Zhang et al. reported the relation between the $h O G G 1$ polymorphism and esophageal cancer risk [13] but meta-analysis by Wang showed no association [11]. In our study, an association between the $h O G G 1$ polymorphism and esophageal cancer risk was found in dominant model in Caucasian population $(p=0.013)$. Previous meta-analysis reported that the hOGG1 polymorphism had a relation to hepatocellular cancer [15]. However, we could not find an association in any model. The results of previous meta-analysis on prostate cancer consisted with ours [17] but we could not find any association in Caucasian population and some studies influenced the results according to sensitivity analysis. Similar to previous study, our study showed the relation between the $h O G G 1$ polymorphism and head and neck cancer [16]. But recessive model in all population analysis showed publication bias and several results except for allele and dominant model in all population analysis and dominant model in Asian population analysis were influenced by some studies according to sensitivity analysis.

From dbSNP database, The $\mathrm{C}$ and $\mathrm{G}$ allele frequencies have been reported to be 0.776 and 0.224 in European, 0.500 and 0.500 in Chinese, 0.477 and 0.523 in Japanese, and 0.856 and 0.144 in Sub-Saharan African populations, respectively. And the CC, CG and GG genotype frequencies have been reported to be 0.621 , 
0.310, and 0.069 in European, 0.244, 0.511, and 0.244 in Chinese, 0.182, 0.591, and 0.227 in Japanese, and 0.746, 0.220 , and 0.034 in Sub-Saharan African populations, respectively. In our results, the $\mathrm{C}$ and $\mathrm{G}$ allele frequencies have been reported to be 0.762 and 0.238 in Caucasian and 0.484 and 0.516 in Asian. And the CC, CG and GG genotype frequencies have been shown to be $0.584,0.356$, and 0.060 in Caucasian and 0.246, 0.477, 0.277 in Asian. We found that the genotype and allele frequencies in Caucasian and Asian showed significant difference, which might affect the roles of the $h O G G 1$ polymorphism on cancer risk in Asians and Caucasians.

This meta-analysis has several limitations. Our results showed the genetic difference and different cancer risks in ethnicity but included studies regarded only Caucasians and Asians, but not other races like African. Because of limited data, we simply divided the ethnicity into Asian and Caucasian. The genetic heterogeneity plays an important role in the carcinogenesis but it is an interaction between environment factors and genetic background. This analysis could not reflect environmental exposures. And there were considerable inadequate data in previous studies, especially in meta-analysis. We had examined the included articles as many as possible such as HWE or data in the article but there could be still omitted data. And several results showed significant associations but revealed publication bias.

\section{CONCLUSIONS}

In spite of some limitations, this meta-analysis could provide the evidence of the strong association between the $h O G G 1$ polymorphism and cancer risk. In summary, G allele of Ser326Cys polymorphism might play a role in the carcinogenesis and the genotype and allele frequencies difference makes the ethnicity difference in carcinogenesis. If further study with large sample size in diverse ethnic populations were performed, it would provide more precise understanding of the association between the $h O G G 1$ polymorphism and various cancer risks. This SNP could be a candidate of biomarker for cancer screening, diagnosis, and therapy in the future.

\section{MATERIAL AND METHODS}

\section{Search strategy}

In order to select eligible studies about the $h O G G 1$ polymorphism and cancer, electronic database including Pubmed, Embase, google of scholar, and KISS were investigated up to April 2015. We searched meta-analysis study about the $h O G G 1$ polymorphism and also searched the association study between the $h O G G 1$ polymorphism and risk of cancer. The keywords to find these studies were following: "8-oxoguanine DNA glycosylase",
"hOGG1", or "DNA repair gene", AND "polymorphism", "polymorphisms", or "variant" AND "Ser326Cys" AND "cancer or carcinoma", or "meta analysis". The previous meta-analysis studies about the $h O G G 1$ polymorphism and cancer were considered as reference.

\section{Inclusion criteria and data extraction}

Selected studies were included in the meta-analysis if they met the following criteria: (1) Investigated the association study between the $h O G G 1$ polymorphism and cancer; (2) A comparison between cancer and control; (3) Included genotype and allele distributions of Ser326Cys polymorphism for genetic analysis. The data of first author's name, year of publication, country of origin, ethnicity of study population, sample size of cancer and control, and genotype frequencies of the hOGG1 polymorphism in cancer and control were extracted from the final selected studies. The allele distributions were calculated from genotype distributions in the cancer group and the control group. The ethnicity was divided into Asian and Caucasian.

\section{Statistical analysis}

HWE in all include studies was tested by the Chisquare test. Meta-analysis was performed using the Comprehensive Meta-analysis software. The pooled $\mathrm{p}$ value, OR, and 95\% CI were used to assess the strength of association between risk of cancer and the hOGG1 polymorphism. All the results were re-analyzed to see the effect of each paper on the final results by sensitivity analysis. The meta-analysis was repeated while omitting each study one at a time to examine the influence of each study on the pooled OR. For the regression analysis in this meta-analysis, the random effects model or the fixed effects model was used. OR with the corresponding 95 $\%$ CI was calculated for the dominant model $(\mathrm{C} / \mathrm{C}+\mathrm{C} / \mathrm{G}$ genotypes vs. $\mathrm{G} / \mathrm{G}$ genotype) and recessive model $(\mathrm{C} / \mathrm{C} v s$. $\mathrm{C} / \mathrm{G}+\mathrm{G} / \mathrm{G}$ genotypes), and allele ( $\mathrm{C} v s . \mathrm{T})$, respectively $[150,151]$. The $p<0.05$ was regarded as statistically significant. A $\chi 2$-test-based Q statistic test was used to assess heterogeneity among studies. We also performed the effect of heterogeneity by $I^{2}$ test. The random-effects Mantel-Haenszel method was adopted if the result of the Q test was $\mathrm{p}<0.05$ or $I^{2}$ statistic was $>50 \%$, which indicated the statistically significant heterogeneity between the studies. Otherwise, the fixed-effects MantelHaenszel method was adopted. When more than 3 studies were included, Begg's funnel plot and Egger's test were performed to evaluated publication bias.

\section{ACKNOWLEDGMENT}

This work was supported by the National Research 
Foundation of Korea (NRF) grant funded by the Korea government (MSIP) (No. 2016R1A2B4012253).

\section{CONFLICTS OF INTEREST}

The authors declare that they have no conflicts of interest.

\section{REFERENCES}

1. Breivik J. The evolutionary origin of genetic instability in cancer development. Semin Cancer Biol. 2005; 15:51-60.

2. Weiss JM, Goode EL, Ladiges WC, Ulrich CM. Polymorphic variation in hOGG1 and risk of cancer: a review of the functional and epidemiologic literature. Mol Carcinog. 2005; 42:127-41.

3. Marnett LJ. Oxyradicals and DNA damage. Carcinogenesis. 2000; 21:361-70

4. Loft S, Deng XS, Tuo J, Wellejus A, Sørensen M, Poulsen HE. Experimental study of oxidative DNA damage. Free Radic Res. 1998; 29:525-39.

5. Sangrajrang S, Schmezer P, Burkholder I, Waas P, Boffetta P, Brennan P, Bartsch H, Wiangnon S, Popanda O. Polymorphisms in three base excision repair genes and breast cancer risk in Thai women. Breast Cancer Res Treat. 2008; 111:279-88.

6. Mohrenweiser HW, Wilson DM 3rd, Jones IM. Challenges and complexities in estimating both the functional impact and the disease risk associated with the extensive genetic variation in human DNA repair genes. Mutat Res. 2003; 526:93-125.

7. Janssen K, Schlink K, Gotte W, Hippler B, Kaina B, Oesch F. DNA repair activity of 8-oxoguanine DNA glycosylase 1 (OGG1) in human lymphocytes is not dependent on genetic polymorphism Ser326/Cys326. Mutat Res. 2001; 486:20716.

8. Floyd RA. The role of 8-hydroxyguanine in carcinogenesis. Carcinogenesis. 1990; 11:1447-50.

9. Li D, Liu H, Yan L, Tang Y, Ren J, Xu Z. Lack of association between hOGG1 Ser326Cys polymorphism and the risk of bladder cancer: a meta-analysis. Urol Int. 2012; 88:88-94.

10. Yuan W, Xu L, Feng Y, Yang Y, Chen W, Wang J, Pang D, Li D. The hOGG1 Ser326Cys polymorphism and breast cancer risk: a meta-analysis. Breast Cancer Res Treat. 2010; 122:835-42.

11. Wang Y, Gao X, Wei F, Zhang X, Yu J, Zhao H, Sun Q, Yan F, Yan C, Li H, Ren X. The hOGG1 Ser326Cys polymorphism contributes to digestive system cancer susceptibility: evidence from 48 case-control studies. Tumour Biol. 2015; 36:1029-38.

12. Zhang M, Mo R. Association of hOGG1 Ser326Cys polymorphism with colorectal cancer risk: an updated metaanalysis including 5235 cases and 8438 controls. Tumour
Biol. 2014; 35:12627-33.

13. Zhang J, Zhou J, Zhang P, Wang W, Tao S, Wang M. A meta-analysis of the association between the hOGG1 Ser326Cys polymorphism and the risk of esophageal squamous cell carcinoma. PLoS One. 2013; 8:e65742.

14. Li BR, Zhou GW, Bian Q, Song B. Lack of association between the hOGG1 Ser326Cys polymorphism and gastric cancer risk: a meta-analysis. Asian Pac J Cancer Prev. 2012; 13:1145-49.

15. Wang W, Dang S, Li Y, Sun M, Jia X, Wang R, Liu J. hOGG1 Ser326Cys polymorphism and risk of hepatocellular carcinoma among East Asians: a metaanalysis. PLoS One. 2013; 8:e60178.

16. Liu J, Cao XL, Zhang Z, Lei DP, Jin T, Yu XM, Pan XL. HOGG1 Ser326Cys polymorphism and susceptibility to head and neck cancer: a meta-analysis. Asian Pac J Cancer Prev. 2011; 12:2491-94.

17. Zhu S, Zhang H, Tang Y, Wang J. Polymorphisms in XPD and hOGG1 and prostate cancer risk: a meta-analysis. Urol Int. 2012; 89:233-40.

18. Geng P, Yao J, Zhu Y. hOGG1 Ser326Cys polymorphism and lung cancer susceptibility: a meta-analysis. Mol Biol Rep. 2014; 41:2299-306.

19. Wei B, Zhou Y, Xu Z, Xi B, Cheng H, Ruan J, Zhu M, Hu Q, Wang Q, Wang Z, Yan Z, Jin K, Zhou D, et al. The effect of hOGG1 Ser326Cys polymorphism on cancer risk: evidence from a meta-analysis. PLoS One. 2011; 6:e27545.

20. Yin ZB, Hua RX, Li JH, Sun C, Zhu JH, Su X, Ji C, Xiang Q, Hua ZM. Smoking and hOGG1 Ser326Cys polymorphism contribute to lung cancer risk: evidence from a meta-analysis. Tumour Biol. 2014; 35:1609-18.

21. Zhen-Bo T, An-Lin F, Ling L, Su-Fang Z. No association between hOGG1 Ser326Cys polymorphism and hepatocellular carcinoma. Hepatogastroenterology. 2013; 60:1101-04.

22. Zhong DY, Chu HY, Wang ML, Ma L, Shi DN, Zhang ZD. Meta-analysis demonstrates lack of association of the hOGG1 Ser326Cys polymorphism with bladder cancer risk. Genet Mol Res. 2012; 11:3490-6.

23. Xu Z, Yu L, Zhang X. Association between the hOGG1 Ser326Cys polymorphism and lung cancer susceptibility: a meta-analysis based on 22,475 subjects. Diagn Pathol. 2013; 8:144.

24. Gu D, Wang M, Zhang Z, Chen J. Lack of association between the hOGG1 Ser326Cys polymorphism and breast cancer risk: evidence from 11 case-control studies. Breast Cancer Res Treat. 2010; 122:527-31.

25. Ahu Z. Studies on the relationship between single nucleotide polymorphisms and susceptibility to hepatocellular carcinoma in Chinese population. Thesis (PhD), Second Military Medical University. 2004.

26. Arizono K, Osada Y, Kuroda Y. DNA repair gene hOGG1 codon 326 and XRCC1 codon 399 polymorphisms and bladder cancer risk in a Japanese population. Jpn J Clin 
Oncol. 2008; 38:186-91.

27. Brevik A, Joshi AD, Corral R, Onland-Moret NC, Siegmund KD, Le Marchand L, Baron JA, Martinez ME, Haile RW, Ahnen DJ, Sandler RS, Lance P, Stern MC. Polymorphisms in base excision repair genes as colorectal cancer risk factors and modifiers of the effect of diets high in red meat. Cancer Epidemiol Biomarkers Prev. 2010; 19:3167-73.

28. Cai Q, Shu XO, Wen W, Courtney R, Dai Q, Gao YT, Zheng W. Functional Ser326Cys polymorphism in the hOGG1 gene is not associated with breast cancer risk. Cancer Epidemiol Biomarkers Prev. 2006; 15:403-04.

29. Canbay E, Agachan B, Gulluoglu M, Isbir T, Balik E, Yamaner S, Bulut T, Cacina C, Eraltan IY, Yilmaz A, Bugra D. Possible associations of APE1 polymorphism with susceptibility and HOGG1 polymorphism with prognosis in gastric cancer. Anticancer Res. 2010; 30:1359-64.

30. Canbay E, Cakmakoglu B, Zeybek U, Sozen S, Cacina C, Gulluoglu M, Balik E, Bulut T, Yamaner S, Bugra D. Association of APE1 and hOGG1 polymorphisms with colorectal cancer risk in a Turkish population. Curr Med Res Opin. 2011; 27:1295-302.

31. Capella G, Pera G, Sala N, Agudo A, Rico F, Del Giudicce G, Plebani M, Palli D, Boeing H, Bueno-de-Mesquita HB, Carneiro F, Berrino F, Vineis P, et al. DNA repair polymorphisms and the risk of stomach adenocarcinoma and severe chronic gastritis in the EPIC-EURGAST study. Int J Epidemiol. 2008; 37:1316-25.

32. Chang $\mathrm{CH}$, Hsiao CF, Chang GC, Tsai YH, Chen YM, Huang MS, Su WC, Hsieh WS, Yang PC, Chen CJ, Hsiung CA. Interactive effect of cigarette smoking with human 8-oxoguanine DNA N-glycosylase 1 (hOGG1) polymorphisms on the risk of lung cancer: a case-control study in Taiwan. Am J Epidemiol. 2009; 170:695-702.

33. Chang JS, Wrensch MR, Hansen HM, Sison JD, Aldrich MC, Quesenberry CP Jr, Seldin MF, Kelsey KT, Wiencke JK. Base excision repair genes and risk of lung cancer among San Francisco Bay Area Latinos and AfricanAmericans. Carcinogenesis. 2009; 30:78-87.

34. Chen L, Elahi A, Pow-Sang J, Lazarus P, Park J. Association between polymorphism of human oxoguanine glycosylase 1 and risk of prostate cancer. J Urol. 2003; 170:2471-74.

35. Cho EY, Hildesheim A, Chen CJ, Hsu MM, Chen IH, Mittl BF, Levine PH, Liu MY, Chen JY, Brinton LA, Cheng YJ, Yang CS. Nasopharyngeal carcinoma and genetic polymorphisms of DNA repair enzymes XRCC1 and hOGG1. Cancer Epidemiol Biomarkers Prev. 2003; 12:1100-04.

36. Choi JY, Hamajima N, Tajima K, Yoo KY, Yoon KS, Park SK, Kim SU, Lee KM, Noh DY, Ahn SH, Choe KJ, Han W, Hirvonen A, Kang D. hOGG1 Ser326Cys polymorphism and breast cancer risk among Asian women. Breast Cancer Res Treat. 2003; 79:59-62.
37. Curtin K, Samowitz WS, Wolff RK, Ulrich CM, Caan BJ, Potter JD, Slattery ML. Assessing tumor mutations to gain insight into base excision repair sequence polymorphisms and smoking in colon cancer. Cancer Epidemiol Biomarkers Prev. 2009; 18:3384-88.

38. De Ruyck K, Szaumkessel M, De Rudder I, Dehoorne A, Vral A, Claes K, Velghe A, Van Meerbeeck J, Thierens H. Polymorphisms in base-excision repair and nucleotideexcision repair genes in relation to lung cancer risk. Mutat Res. 2007; 631:101-10.

39. De Ruyck K, Van Eijkeren M, Claes K, Morthier R, De Paepe A, Vral A, De Ridder L, Thierens H. Radiationinduced damage to normal tissues after radiotherapy in patients treated for gynecologic tumors: association with single nucleotide polymorphisms in XRCC1, XRCC3, and OGG1 genes and in vitro chromosomal radiosensitivity in lymphocytes. Int J Radiat Oncol Biol Phys. 2005; 62:114049.

40. Dhillon VS, Yeoh E, Fenech M. DNA repair gene polymorphisms and prostate cancer risk in South Australia-results of a pilot study. Urol Oncol. 2009; 29:641-46.

41. Dianzani I, Gibello L, Biava A, Giordano M, Bertolotti M, Betti M, Ferrante D, Guarrera S, Betta GP, Mirabelli D, Matullo G, Magnani C. Polymorphisms in DNA repair genes as risk factors for asbestos-related malignant mesothelioma in a general population study. Mutat Res. 2006; 599:124-34.

42. Elahi A, Zheng Z, Park J, Eyring K, McCaffrey T, Lazarus P. The human OGG1 DNA repair enzyme and its association with orolaryngeal cancer risk. Carcinogenesis. 2002; 23:1229-34.

43. Engin AB, Karahalil B, Engin A, Karakaya AE. Oxidative stress, Helicobacter pylori, and OGG1 Ser326Cys, XPC Lys939Gln, and XPD Lys751Gln polymorphisms in a Turkish population with colorectal carcinoma. Genet Test Mol Biomarkers. 2010; 14:559-64.

44. Engin AB, Karahalil B, Engin A, Karakaya AE. DNA repair enzyme polymorphisms and oxidative stress in a Turkish population with gastric carcinoma. Mol Biol Rep. 2011; 38:5379-86.

45. Farinati F, Cardin R, Bortolami M, Nitti D, Basso D, de Bernard M, Cassaro M, Sergio A, Rugge M. Oxidative DNA damage in gastric cancer: CagA status and OGG1 gene polymorphism. Int J Cancer. 2008; 123:51-55.

46. Ferguson HR, Wild CP, Anderson LA, Murphy SJ, Johnston BT, Murray LJ, Watson RG, McGuigan J, Reynolds JV, Hardie LJ. No association between hOGG1, XRCC1, and XPD polymorphisms and risk of reflux esophagitis, Barrett's esophagus, or esophageal adenocarcinoma: results from the factors influencing the Barrett's adenocarcinoma relationship case-control study. Cancer Epidemiol Biomarkers Prev. 2008; 17:736-39.

47. Gangwar R, Ahirwar D, Mandhani A, Mittal RD. Do DNA repair genes OGG1, XRCC3 and XRCC7 have an impact on susceptibility to bladder cancer in the North Indian 
population? Mutat Res. 2009; 680:56-63.

48. Gao F. The study of the relationship between the polymorphism of $\mathrm{h}$ OGG1 genes and XPD genes and susceptibility to lung cancer. Master degree thesis, Kunming Medical College, China. 2009.

49. Garcia-Quispes WA, Perez-Machado G, Akdi A, Pastor S, Galofre P, Biarnes F, Castell J, Velazquez A, Marcos R. Association studies of OGG1, XRCC1, XRCC2 and XRCC3 polymorphisms with differentiated thyroid cancer. Mutat Res. 2011; 709-710:67-72.

50. Gil J, Ramsey D, Stembalska A, Karpinski P, Pesz KA, Laczmanska I, Leszczynski P, Grzebieniak Z, Sasiadek MM. The C/A polymorphism in intron 11 of the XPC gene plays a crucial role in the modulation of an individual's susceptibility to sporadic colorectal cancer. Mol Biol Rep. 2012; 39:527-34.

51. Gorgens H, Muller A, Kruger S, Kuhlisch E, Konig IR, Ziegler A, Schackert HK, Eckelt U. Analysis of the base excision repair genes MTH1, OGG1 and MUTYH in patients with squamous oral carcinomas. Oral Oncol. 2007; 43:791-95.

52. Hanaoka T, Sugimura H, Nagura K, Ihara M, Li XJ, Hamada GS, Nishimoto I, Kowalski LP, Yokota J, Tsugane S. hOGG1 exon7 polymorphism and gastric cancer in casecontrol studies of Japanese Brazilians and non-Japanese Brazilians. Cancer Lett. 2001; 170:53-61.

53. Hansen R, Saebo M, Skjelbred CF, Nexo BA, Hagen PC, Bock G, Bowitz Lothe IM, Johnson E, Aase S, Hansteen IL, Vogel U, Kure EH. GPX Pro198Leu and OGG1 Ser326Cys polymorphisms and risk of development of colorectal adenomas and colorectal cancer. Cancer Lett. 2005; 229:8591.

54. Hansen RD, Krath BN, Frederiksen K, Tjonneland A, Overvad K, Roswall N, Loft S, Dragsted LO, Vogel U, Raaschou-Nielsen O. GPX1 Pro(198)Leu polymorphism, erythrocyte GPX activity, interaction with alcohol consumption and smoking, and risk of colorectal cancer. Mutat Res. 2009; 664:13-9.

55. Hao B, Wang H, Zhou K, Li Y, Chen X, Zhou G, Zhu Y, Miao X, Tan W, Wei Q, Lin D, He F. Identification of genetic variants in base excision repair pathway and their associations with risk of esophageal squamous cell carcinoma. Cancer Res. 2004; 64:4378-84.

56. Hatt L, Loft S, Risom L, Møller P, Sørensen M, RaaschouNielsen O, Overvad K, Tjønneland A, Vogel U. OGG1 expression and OGG1 Ser326Cys polymorphism and risk of lung cancer in a prospective study. Mutat Res. 2008; 639:45-54.

57. Ming-Shiean H, Yu JC, Wang HW, Chen ST, Hsiung CN, Ding SL, Wu PE, Shen CY, Cheng CW. Synergistic Effects of Polymorphisms in DNA Repair Genes and Endogenous Estrogen Exposure on Female Breast Cancer Risk. Ann Surg Oncol. 2010; 17:760-71.

58. Hu H, Wu J, Jin Y, Zhang L, Gao G. hOGG1 genotype with susceptibility to esophageal cancer in Northern Henan regions. Shandong Yiyao. 2010; 50:2.

59. Huang C, Chen J, Yang S, Cheng C, Chern H, Chang K, $\mathrm{Wu}$ P, Shen C. Breast cancer risk associated with genotypic polymorphism of oxidative DNA damage repair genes-a multigenic study of base excision repair and transcriptioncoupled repair in cancer susceptibility. J Genet Mol Biol. 2004; 15:116-36.

60. Huang WY, Gao YT, Rashid A, Sakoda LC, Deng J, Shen MC, Wang BS, Han TQ, Zhang BH, Chen BE, Rosenberg PS, Chanock SJ, Hsing AW. Selected base excision repair gene polymorphisms and susceptibility to biliary tract cancer and biliary stones: a population-based case-control study in China. Carcinogenesis. 2008; 29:100-5.

61. Hung RJ, Brennan P, Canzian F, Szeszenia-Dabrowska N, Zaridze D, Lissowska J, Rudnai P, Fabianova E, Mates D, Foretova L, Janout V, Bencko V, Chabrier A, et al. Large-scale investigation of base excision repair genetic polymorphisms and lung cancer risk in a multicenter study. J Natl Cancer Inst. 2005; 97:567-76.

62. Ito H, Hamajima N, Takezaki T, Matsuo K, Tajima K, Hatooka S, Mitsudomi T, Suyama M, Sato S, Ueda R. A limited association of OGG1 Ser326Cys polymorphism for adenocarcinoma of the lung. J Epidemiol. 2002; 12:258-65.

63. Janik J, Swoboda M, Janowska B, Ciesla JM, Gackowski D, Kowalewski J, Olinski R, Tudek B, Speina E. 8-Oxoguanine incision activity is impaired in lung tissues of NSCLC patients with the polymorphism of OGG1 and XRCC1 genes. Mutat Res. 2011; 709-710:21-31.

64. Jin MJ, Liu B, Zhang SS, Zhang YJ, Xu M, Ma XY, Yao KY, Chen K. Application of multifactor dimensionality reduction on the interactions between gene-gene, geneenvironment and the risk sporadic colorectal cancer in Chinese population. Zhonghua Liu Xing Bing Xue Za Zhi. 2008; 29:535-39.

65. Jung SW, Park NH, Shin JW, Park BR, Kim CJ, Lee JE, Shin ES, Kim JA, Chung YH. Polymorphisms of DNA repair genes in Korean hepatocellular carcinoma patients with chronic hepatitis B: possible implications on survival. J Hepatol. 2012; 57:621-27.

66. Karahalil B, Emerce E, Kocer B, Han S, Alkis N, Karakaya AE. The association of OGG1 Ser326Cys polymorphism and urinary 8-OHdG levels with lung cancer susceptibility: a hospital-based case-control study in Turkey. Arh Hig Rada Toksikol. 2008; 59:241-50.

67. Kasahara M, Osawa K, Yoshida K, Miyaishi A, Osawa Y, Inoue N, Tsutou A, Tabuchi Y, Tanaka K, Yamamoto M, Shimada E, Takahashi J. Association of MUTYH Gln324His and APEX1 Asp148Glu with colorectal cancer and smoking in a Japanese population. J Exp Clin Cancer Res. 2008; 27:49.

68. Kim EJ, Jeong P, Quan C, Kim J, Bae SC, Yoon SJ, Kang JW, Lee SC, Jun Wee J, Kim WJ. Genotypes of TNF-alpha, VEGF, hOGG1, GSTM1, and GSTT1: useful determinants for clinical outcome of bladder cancer. Urology. 2005; 
$65: 70-5$.

69. Kim JI, Park YJ, Kim KH, Kim JI, Song BJ, Lee MS, Kim CN, Chang SH. hOGG1 Ser326Cys polymorphism modifies the significance of the environmental risk factor for colon cancer. World J Gastroenterol. 2003; 9:956-60.

70. Kohno T, Kunitoh H, Mimaki S, Shiraishi K, Kuchiba A, Yamamoto S, Yokota J. Contribution of the TP53, OGG1, CHRNA3, and HLA-DQA1 genes to the risk for lung squamous cell carcinoma. J Thorac Oncol. 2011; 6:813-17.

71. Kohno T, Kunitoh H, Toyama K, Yamamoto S, Kuchiba A, Saito D, Yanagitani N, Ishihara S, Saito R, Yokota J. Association of the OGG1-Ser326Cys polymorphism with lung adenocarcinoma risk. Cancer Sci. 2006; 97:724-28.

72. Kohno T, Shinmura K, Tosaka M, Tani M, Kim SR, Sugimura H, Nohmi T, Kasai H, Yokota J. Genetic polymorphisms and alternative splicing of the hOGG1 gene, that is involved in the repair of 8-hydroxyguanine in damaged DNA. Oncogene. 1998; 16:3219-25.

73. Krupa R, Sobczuk A, Popławski T, Wozniak K, Blasiak J. DNA damage and repair in endometrial cancer in correlation with the hOGG1 and RAD51 genes polymorphism. Mol Biol Rep. 2011; 38:1163-70.

74. Laantri N, Jalbout M, Khyatti M, Ayoub WB, Dahmoul S, Ayad M, Bedadra W, Abdoun M, Mesli S, Kandil M, Hamdi-Cherif M, Boualga K, Bouaouina N, et al. XRCC1 and hOGG1 genes and risk of nasopharyngeal carcinoma in North African countries. Mol Carcinog. 2011; 50:732-37.

75. Lagadu S, Lechevrel M, Sichel F, Breton J, Pottier D, Couderc R, Moussa F, Prevost V. 8-oxo-7,8-dihydro2'-deoxyguanosine as a biomarker of oxidative damage in oesophageal cancer patients: lack of association with antioxidant vitamins and polymorphism of hOGG1 and GST. J Exp Clin Cancer Res. 2010; 29:157.

76. Lan Q, Mumford JL, Shen M, Demarini DM, Bonner MR, He X, Yeager M, Welch R, Chanock S, Tian L, Chapman RS, Zheng T, Keohavong P, et al. Oxidative damage-related genes AKR1C3 and OGG1 modulate risks for lung cancer due to exposure to PAH-rich coal combustion emissions. Carcinogenesis. 2004; 25:2177-81.

77. Le Marchand L, Donlon T, Lum-Jones A, Seifried A, Wilkens LR. Association of the hOGG1 Ser326Cys polymorphism with lung cancer risk. Cancer Epidemiol Biomarkers Prev. 2002; 11:409-12.

78. Li D, Suzuki H, Liu B, Morris J, Liu J, Okazaki T, Li Y, Chang P, Abbruzzese JL. DNA repair gene polymorphisms and risk of pancreatic cancer. Clin Cancer Res. 2009; 15:740-46.

79. Li Q, Huang L, Rong L, Xue Y, Lu Q, Rui Y, Li J, Tong N, Wang M, Zhang Z, Fang Y. hOGG1 Ser326Cys polymorphism and risk of childhood acute lymphoblastic leukemia in a Chinese population. Cancer Sci. 2011; 102:1123-27.

80. Li QD, Li H, Wang MS, Diao TY, Zhou ZY, Fang QX, Yang FY, Li QH. Multi-susceptibility genes associated with the risk of the development stages of esophageal squamous cell cancer in Feicheng County. BMC Gastroenterol. 2011; 11:74.

81. Li Z, Guan W, Li MX, Zhong ZY, Qian CY, Yang XQ, Liao L, Li ZP, Wang D. Genetic polymorphism of DNA base-excision repair genes (APE1, OGG1 and XRCC1) and their correlation with risk of lung cancer in a Chinese population. Arch Med Res. 2011; 42:226-34.

82. Liu R, Yin L, Pu Y, Liu Y, Hu X, Liang G. Relationship between human 8-hydroxyguanine glycosylase Ser326Cys gene polymorphism and esophageal cancer. China Pub Health. 2005; 12:1430-32.

83. Liu X, Xiao N, Guo W, Wu Y, Cai Z, He Q, Zhang L, Chen $\mathrm{X}$, Sun C, Wang J, Zhu C, Jin H, Wang Y. The hOGG1 gene 5 '-UTR variant c.-53G $>\mathrm{C}$ contributes to the risk of gastric cancer but not colorectal cancer in the Chinese population: the functional variation of hOGG1 for gastric cancer risk. J Cancer Res Clin Oncol. 2011; 137:1477-85.

84. Loft S, Svoboda P, Kasai H, Tjonneland A, Vogel U, Moller P, Overvad K, Raaschou-Nielsen O. Prospective study of 8-oxo-7,8-dihydro-2'-deoxyguanosine excretion and the risk of lung cancer. Carcinogenesis. 2006; 27:1245-50.

85. Loizidou MA, Michael T, Neuhausen SL, Newbold RF, Marcou Y, Kakouri E, Daniel M, Papadopoulos P, Malas S, Hadjisavvas A, Kyriacou K. DNA-repair genetic polymorphisms and risk of breast cancer in Cyprus. Breast Cancer Res Treat. 2009; 115:623-27.

86. Malik MA, Zargar SA, Mittal B. Lack of influence of DNA repair gene OGG1 codon 326 polymorphisms of gastric cancer risk in the Kashmir valley. Asian Pac J Cancer Prev. 2010; 11:165-68.

87. Marques CR, Da Silva TM, De Albuquerque DM, Chaves MS, Marques Filho MF, Oliveira JS, Di Pietro G, Sousa SM, Simoes AL, Rios-Santos F. NAT2, XRCC1 and hOGG1 polymorphisms, cigarette smoking, alcohol consumption and risk of upper aerodigestive tract cancer. Anticancer Res. 2014; 34:3217-24.

88. Matullo G, Dunning AM, Guarrera S, Baynes C, Polidoro S, Garte S, Autrup H, Malaveille C, Peluso M, Airoldi L, Veglia F, Gormally E, Hoek G, et al. DNA repair polymorphisms and cancer risk in non-smokers in a cohort study. Carcinogenesis. 2006; 27:997-1007.

89. McWilliams RR, Bamlet WR, Cunningham JM, Goode EL, de Andrade M, Boardman LA, Petersen GM. Polymorphisms in DNA repair genes, smoking, and pancreatic adenocarcinoma risk. Cancer Res. 2008; 68:4928-35.

90. Miyaishi A, Osawa K, Osawa Y, Inoue N, Yoshida K, Kasahara M, Tsutou A, Tabuchi Y, Sakamoto K, Tsubota N, Takahashi J. MUTYH Gln324His gene polymorphism and genetic susceptibility for lung cancer in a Japanese population. J Exp Clin Cancer Res. 2009; 28:10.

91. Moreno V, Gemignani F, Landi S, Gioia-Patricola L, Chabrier A, Blanco I, Gonzalez S, Guino E, Capella G, 
Canzian F. Polymorphisms in genes of nucleotide and base excision repair: risk and prognosis of colorectal cancer. Clin Cancer Res. 2006; 12:2101-8.

92. Niwa Y, Matsuo K, Ito H, Hirose K, Tajima K, Nakanishi T, Nawa A, Kuzuya K, Tamakoshi A, Hamajima N. Association of XRCC1 Arg399Gln and OGG1 Ser326Cys polymorphisms with the risk of cervical cancer in Japanese subjects. Gynecol Oncol. 2005; 99:43-9.

93. Obtulowicz T, Swoboda M, Speina E, Gackowski D, Rozalski R, Siomek A, Janik J, Janowska B, Ciesla JM, Jawien A, Banaszkiewicz Z, Guz J, Dziaman T, et al. Oxidative stress and 8-oxoguanine repair are enhanced in colon adenoma and carcinoma patients. Mutagenesis. 2010; 25:463-71.

94. Okasaka T, Matsuo K, Suzuki T, Ito H, Hosono S, Kawase T, Watanabe M, Yatabe Y, Hida T, Mitsudomi T, Tanaka H, Yokoi K, Tajima K. hOGG1 Ser326Cys polymorphism and risk of lung cancer by histological type. J Hum Genet. 2009; 54:739-45.

95. Palli D, Polidoro S, D'Errico M, Saieva C, Guarrera S, Calcagnile AS, Sera F, Allione A, Gemma S, Zanna I, Filomena A, Testai E, Caini S, et al. Polymorphic DNA repair and metabolic genes: a multigenic study on gastric cancer. Mutagenesis. 2010; 25:569-75.

96. Pardini B, Naccarati A, Novotny J, Smerhovsky Z, Vodickova L, Polakova V, Hanova M, Slyskova J, Tulupova E, Kumar R, Bortlik M, Barale R, Hemminki $\mathrm{K}$, et al. DNA repair genetic polymorphisms and risk of colorectal cancer in the Czech Republic. Mutat Res. 2008; 638:146-53.

97. Park J, Chen L, Tockman MS, Elahi A, Lazarus P. The human 8-oxoguanine DNA N-glycosylase 1 (hOGG1) DNA repair enzyme and its association with lung cancer risk. Pharmacogenetics. 2004; 14:103-9.

98. Pawlowska E, Janik-Papis K, Rydzanicz M, Zuk K, Kaczmarczyk D, Olszewski J, Szyfter K, Blasiak J, Morawiec-Sztandera A. The Cys326 allele of the 8-oxoguanine DNA N-glycosylase 1 gene as a risk factor in smoking- and drinking-associated larynx cancer. Tohoku J Exp Med. 2009; 219:269-75.

99. Poplawski T, Arabski M, Kozirowska D, BlasinskaMorawiec M, Morawiec Z, Morawiec-Bajda A, Klupinska G, Jeziorski A, Chojnacki J, Blasiak J. DNA damage and repair in gastric cancer--a correlation with the hOGG1 and RAD51 genes polymorphisms. Mutat Res. 2006; 601:83-91.

100. Przybylowska K, Kabzinski J, Sygut A, Dziki L, Dziki A, Majsterek I. An association selected polymorphisms of XRCC1, OGG1 and MUTYH gene and the level of efficiency oxidative DNA damage repair with a risk of colorectal cancer. Mutat Res. 2013; 745-746:6-15.

101. Qian B, Zhang H, Zhang L, Zhou X, Yu H, Chen K. Association of genetic polymorphisms in DNA repair pathway genes with non-small cell lung cancer risk. Lung Cancer. 2011; 73:138-46.
102. Roberts MR, Shields PG, Ambrosone CB, Nie J, Marian C, Krishnan SS, Goerlitz DS, Modali R, Seddon M, Lehman T, Amend KL, Trevisan M, Edge SB, et al. Single-nucleotide polymorphisms in DNA repair genes and association with breast cancer risk in the web study. Carcinogenesis. 2011; $32: 1223-30$.

103. Romanowicz-Makowska H, Smolarz B, Makowski M, Połać I, Pertyński T. Ser326Cys polymorphism in DNA repair genes hOGG1 in breast cancer women. Pol J Pathol. 2008; 59:201-4.

104. Rossner P Jr, Terry MB, Gammon MD, Zhang FF, Teitelbaum SL, Eng SM, Sagiv SK, Gaudet MM, Neugut AI, Santella RM. OGG1 polymorphisms and breast cancer risk. Cancer Epidemiol Biomarkers Prev. 2006; 15:811-15.

105. Sakamoto T, Higaki Y, Hara M, Ichiba M, Horita M, Mizuta T, Eguchi Y, Yasutake T, Ozaki I, Yamamoto K, Onohara S, Kawazoe S, Shigematsu H, et al. hOGG1 Ser326Cys polymorphism and risk of hepatocellular carcinoma among Japanese. J Epidemiol. 2006; 16:233-39.

106. Sameer AS, Nissar S, Abdullah S, Chowdri NA, Siddiqi MA. DNA repair gene 8-oxoguanine DNA glycosylase Ser326Cys polymorphism and colorectal cancer risk in a Kashmiri population. DNA Cell Biol. 2012; 31:541-46.

107. Shinmura K, Kohno T, Kasai H, Koda K, Sugimura H, Yokota J. Infrequent mutations of the hOGG1 gene, that is involved in the excision of 8-hydroxyguanine in damaged DNA, in human gastric cancer. Jpn J Cancer Res. 1998; 89:825-28.

108. Sliwinski T, Krupa R, Wisniewska-Jarosinska M, Pawlowska E, Lech J, Chojnacki J, Blasiak J. Common polymorphisms in the XPD and hOGG1 genes are not associated with the risk of colorectal cancer in a Polish population. Tohoku J Exp Med. 2009; 218:185-91.

109. Sliwinski T, Przybylowska K, Markiewicz L, Rusin P, Pietruszewska W, Zelinska-Blizniewska H, Olszewski J, Morawiec-Sztandera A, Mlynarski W, Majsterek I. MUTYH Tyr165Cys, OGG1 Ser326Cys and XPD Lys751Gln polymorphisms and head neck cancer susceptibility: a case control study. Mol Biol Rep. 2011; 38:1251-61.

110. Smolarz B, Makowska M, Samulak D, Michalska MM, Mojs E, Wilczak M, Romanowicz H. Single nucleotide polymorphisms (SNPs) of ERCC2, hOGG1, and XRCC1 DNA repair genes and the risk of triple-negative breast cancer in Polish women. Tumour Biol. 2014; 35:3495-502.

111. Sørensen M, Raaschou-Nielsen O, Hansen RD, Tjonneland A, Overvad K, Vogel U. Interactions between the OGG1 Ser326Cys polymorphism and intake of fruit and vegetables in relation to lung cancer. Free Radic Res. 2006; 40:885-91.

112. Srivastava K, Srivastava A, Mittal B. Polymorphisms in ERCC2, MSH2, and OGG1 DNA repair genes and gallbladder cancer risk in a population of Northern India. Cancer. 2010; 116:3160-69.

113. Stanczyk M, Sliwinski T, Cuchra M, Zubowska M, 
Bielecka-Kowalska A, Kowalski M, Szemraj J, Mlynarski W, Majsterek I. The association of polymorphisms in DNA base excision repair genes XRCC1, OGG1 and MUTYH with the risk of childhood acute lymphoblastic leukemia. Mol Biol Rep. 2011; 38:445-51.

114. Sterpone S, Mastellone V, Padua L, Novelli F, Patrono C, Cornetta T, Giammarino D, Donato V, Testa A, Cozzi R. Single-nucleotide polymorphisms in BER and HRR genes, XRCC1 haplotypes and breast cancer risk in Caucasian women. J Cancer Res Clin Oncol. 2010; 136:631-36.

115. Sugimura H, Kohno T, Wakai K, Nagura K, Genka K, Igarashi H, Morris BJ, Baba S, Ohno Y, Gao C, Li Z, Wang J, Takezaki T, et al. hOGG1 Ser326Cys polymorphism and lung cancer susceptibility. Cancer Epidemiol Biomarkers Prev. 1999; 8:669-74.

116. Sun LM, Shang Y, Zeng YM, Deng YY, Cheng JF. HOGG1 polymorphism in atrophic gastritis and gastric cancer after Helicobacter pylori eradication. World J Gastroenterol. 2010; 16:4476-82.

117. Sunaga N, Kohno T, Yanagitani N, Sugimura H, Kunitoh H, Tamura T, Takei Y, Tsuchiya S, Saito R, Yokota J. Contribution of the NQO1 and GSTT1 polymorphisms to lung adenocarcinoma susceptibility. Cancer Epidemiol Biomarkers Prev. 2002; 11:730-38.

118. Synowiec E, Stefanska J, Morawiec Z, Blasiak J, Wozniak $\mathrm{K}$. Association between DNA damage, DNA repair genes variability and clinical characteristics in breast cancer patients. Mutat Res. 2008; 648:65-72.

119. Tang Y, Li X, Liu T, Yang J, Luo J, Luo J, Liang Z. Genetic polymorphisms of DNA repair genes in patients with hepatocellular carcinoma. Shandong Yiyao. 2011; 51:1920.

120. Tsukino H, Hanaoka T, Otani T, Iwasaki M, Kobayashi M, Hara M, Natsukawa S, Shaura K, Koizumi Y, Kasuga Y, Tsugane S. hOGG1 Ser326Cys polymorphism, interaction with environmental exposures, and gastric cancer risk in Japanese populations. Cancer Sci. 2004; 95:977-83.

121. Vogel U, Nexø BA, Olsen A, Thomsen B, Jacobsen NR, Wallin H, Overvad K, Tjønneland A. No association between OGG1 Ser326Cys polymorphism and breast cancer risk. Cancer Epidemiol Biomarkers Prev. 2003; 12:170-71.

122. Vogel U, Nexø BA, Wallin H, Overvad K, Tjønneland A, Raaschou-Nielsen O. No association between base excision repair gene polymorphisms and risk of lung cancer. Biochem Genet. 2004; 42:453-60.

123. Vogel U, Olsen A, Wallin H, Overvad K, Tjønneland A, Nexø BA. No association between OGG1 Ser326Cys and risk of basal cell carcinoma. Cancer Epidemiol Biomarkers Prev. 2004; 13:1680-81.

124. Wang A, Cong W, He X, Jia H, Jin X, et al. A hOGG1 gene polymorhism and genetic susceptibility to colorectal cancer and hepatocellular carcinoma. Chin J Gastroenterol Hepatol. 2008; 17:854-57.

125. Wang W, Wu Y. WU Y. Genetic polymorphism in Hoggle and susceptibility to lung cancer. Carcinog Teratogenesis Mutagen. 2005; 17:101-3.

126. Wang Y, Zhang C, Chen Y, Deng Y, Ma Y, Ju L. Relationship between hOGG1 gene polymorphism and the susceptibility of esophageal cancer in Kazakh nationality. Xinjiang Yike Daxue Xuebao. 2009; 32:539-542.

127. Wikman H, Risch A, Klimek F, Schmezer P, Spiegelhalder B, Dienemann H, Kayser K, Schulz V, Drings P, Bartsch H. hOGG1 polymorphism and loss of heterozygosity ( $\mathrm{LOH})$ : significance for lung cancer susceptibility in a caucasian population. Int J Cancer. 2000; 88:932-37.

128. Wu X, Gu J, Grossman HB, Amos CI, Etzel C, Huang M, Zhang Q, Millikan RE, Lerner S, Dinney CP, Spitz MR. Bladder cancer predisposition: a multigenic approach to DNA-repair and cell-cycle-control genes. Am J Hum Genet. 2006; 78:464-79.

129. Xie H, Xia K, Rong H, Chen X. Genetic polymorphism in hOGG1 is associated with triple-negative breast cancer risk in Chinese Han women. Breast. 2013; 22:707-12.

130. Xing DY, Tan W, Song N, Lin DX. Ser326Cys polymorphism in hOGG1 gene and risk of esophageal cancer in a Chinese population. Int J Cancer. 2001; 95:14043.

131. Xu J, Zheng SL, Turner A, Isaacs SD, Wiley KE, Hawkins GA, Chang BL, Bleecker ER, Walsh PC, Meyers DA, Isaacs WB. Associations between hOGG1 sequence variants and prostate cancer susceptibility. Cancer Res. 2002; 62:2253-57.

132. Yang Y, Tian H, Zhang ZJ. [Association of the XRCC1 and hOGG1 polymorphisms with the risk of laryngeal carcinoma]. [Article in Chinese]. Zhonghua Yi Xue Yi Chuan Xue Za Zhi. 2008; 25:211-13.

133. Yuan T, Wei J, Luo J, Liu M, Deng S, Chen P. Polymorphisms of base-excision repair genes hOGG1 326cys and XRCC1 280His increase hepatocellular carcinoma risk. Dig Dis Sci. 2012; 57:2451-57.

134. Yun SJ, Ha YS, Chae Y, Kim JS, Kim IY, Kim WJ. The hOGG1 mutant genotype is associated with prostate cancer susceptibility and aggressive clinicopathological characteristics in the Korean population. Ann Oncol. 2012; 23:401-5.

135. Zhang H, Hao B, He F. Impact of DNA repair gene hOGG1 Ser326Cys polymorphism on the risk of hepatocellular carcinoma. World Chin J Digestology. 2006; 14:2311-14.

136. Zhang J, Dhakal IB, Greene G, Lang NP, Kadlubar FF. Polymorphisms in hOGG1 and XRCC1 and risk of prostate cancer: effects modified by plasma antioxidants. Urology. 2010; 75:779-85.

137. Zhang Y, Newcomb PA, Egan KM, Titus-Ernstoff L, Chanock S, Welch R, Brinton LA, Lissowska J, BardinMikolajczak A, Peplonska B, Szeszenia-Dabrowska N, Zatonski W, Garcia-Closas M. Genetic polymorphisms in base-excision repair pathway genes and risk of breast cancer. Cancer Epidemiol Biomarkers Prev. 2006; 15:353- 
58.

138. Zhang Z, Shi Q, Wang LE, Sturgis EM, Spitz MR, ElNaggar AK, Hong WK, Wei Q. No Association between hOGG1 Ser326Cys polymorphism and risk of squamous cell carcinoma of the head and neck. Cancer Epidemiol Biomarkers Prev. 2004; 13:1081-83.

139. Zhao H, Qin C, Yan F, Wu B, Cao Q, Wang M, Zhang Z, Yin C. hOGG1 Ser326Cys polymorphism and renal cell carcinoma risk in a Chinese population. DNA Cell Biol. 2011; 30:317-21.

140. Zhou C. Case-control study on the association between single nucleotide polymorphism (SNP) of ERCCZ/XPD and hOGGI and prostate cancer susceptibility. HangHangzhou, Zhejiang University 2011.

141. Zhou C, Xie LP, Lin YW, Yang K, Mao QQ, Cheng Y. Susceptibility of XPD and hOGG1 genetic variants to prostate cancer. Biomed Rep. 2014; 1:679-83.

142. Zhu X, Zhang H, Du H, Hao Q, Wu X, Wang Y. Association of hOGG1 Polymorphism Ser326Cys between the Susceptibility of Esophageal Cancer and Its Clinicopathological Characteristics. Huanjing Yu Zhiye Yixue. 2009; 26:125-28.

143. Alanazi M, Pathan AAK, Shaik JP, Alhadheq A, Khan Z, Khan W, Al Naeem A, Parine NR. The hOGG1 Ser326Cys Gene Polymorphism and Breast Cancer Risk in Saudi Population. Pathol Oncol Res. 2017; 23:525-35.

144. Paz-Elizur T, Krupsky M, Blumenstein S, Elinger D, Schechtman E, Livneh Z. DNA repair activity for oxidative damage and risk of lung cancer. J Natl Cancer Inst. 2003; 95:1312-19.
145. Mambo E, Chatterjee A, de Souza-Pinto NC, Mayard S, Hogue BA, Hoque MO, Dizdaroglu M, Bohr VA, Sidransky D. Oxidized guanine lesions and hOggl activity in lung cancer. Oncogene. 2005; 24:4496-508.

146. Kohno Y, Yamamoto H, Hirahashi M, Kumagae Y, Nakamura M, Oki E, Oda Y. Reduced MUTYH, MTH1, and OGG1 expression and TP53 mutation in diffuse-type adenocarcinoma of gastric cardia. Hum Pathol. 2016; 52:145-52.

147. Kershaw RM, Hodges NJ. Repair of oxidative DNA damage is delayed in the Ser326Cys polymorphic variant of the base excision repair protein OGG1. Mutagenesis. 2012; 27:501-10.

148. Agalliu I, Kwon EM, Salinas CA, Koopmeiners JS, Ostrander EA, Stanford JL. Genetic variation in DNA repair genes and prostate cancer risk: results from a populationbased study. Cancer Causes Control. 2010; 21:289-300.

149. Ding DP, Zhang Y, He XF. Lack of association between hOGG1 Ser326Cys polymorphism and breast cancer susceptibility in European population. Breast Cancer Res Treat. 2011; 129:1023-26.

150. Seok H, Kim SK, Yoo KH, Lee BC, Kim YO, Chung JH. Association of BID SNPs (rs8190315 and rs2072392) and clinical features of benign prostate hyperplasia in Korean population. J Exerc Rehabil. 2014; 10:383-88.

151. Kim SK, Park HK, Choi HS, Yoo KH, Chung JH. Association study of polymorphisms of epidermal growth factor and epidermal growth factor receptor with benign prostatic hyperplasia in a Korean population. Int Neurourol J. 2016; 20:363-70. 